\title{
Leonard Covello
}

The Social Background of the Italo-American School Child: A Study of the Southem Italian Family Mores and Their Effect on the School Situr ation in Italy and America.

Edited and with an introduction by Francesco Cordasco xxxii, 488 pp.

50 guilders

\section{E. J. Brill, Publishers}

\section{Leiden, Netherlands}

An in-depth study of the acculturation of a minority's children; the context of poverty, and its challenges to the American School.

You will want this important volume ...

\section{American Reading Instruction}

\section{by Nila Banton Smith}

This popular history of reading instruction in the United States depicts how past generations of teachers have taught reading, as well as how the present generation teaches it. Descriptions of the latest teaching methods and the most recently published materials in the field of reading are presented.

Written by the well-known educator, author, and reading specialist, Dr. Nila Banton Smith, this well-documented volume is a valuable reference for everyone interested in the history of reading instruction in the United States.

Clothbound, 449 pages

List Price: $\$ 4.95$

Send orders to:

\section{International Reading Association}

Box 695

Newark, Delaware 19711 


\section{TEACHERS COLLEGE PRESS}

Just Published

Colonel Francis Parker

The Children's Crusader

Jack K. Campbell

Parker's impact on the shaping of American education becomes evident in this significant biography. His vital personal involvements in the great events of his time, together with his association with such notable contemporaries as the Adamses and John Dewey, are treated with rare insight and careful scholarship. Cloth, $\$ 5.00$

Progressive Education:

From Arcady to Academe

Patricia Albjerg Graham

In this first comprehensive history of the Progressive Education Association, the influence of leading practitioners is traced with great care. The institutionalization of an idea is here detailed and documented, with much closer attention to internal disputes within the movement than is offered by any other published work dealing with the period.

Cloth, $\$ 5.75$

$$
\begin{gathered}
\text { Teachers College Press } \\
\text { Teachers College, Columbia University } \\
525 \text { W. 120th St. } \\
\text { New York, N.Y. 10027 }
\end{gathered}
$$




\section{Leonard Covello}

The Social Background of the Italo-American School Child: A Study of the Southem Italian Family Mores and Their Effect on the School Situation in Italy and America.

Edited and with an introduction by Francesco Cordasco xxxii, 488 pp.

50 guilders

\section{E. J. Brill, Publishers}

\section{Leiden, Netherlands}

An in-depth study of the acculturation of a minority's children; the context of poverty, and its challenges to the American School.

You will want this important volume ...

\section{American Reading Instruction}

by Nila Banton Smith

This popular history of reading instruction in the United States depicts how past generations of teachers have taught reading, as well as how the present generation teaches it. Descriptions of the latest teaching methods and the most recently published materials in the field of reading are presented.

Written by the well-known educator, author, and reading specialist, Dr. Nila Banton Smith, this well-documented volume is a valuable reference for everyone interested in the history of reading instruction in the United States.

Clothbound, 449 pages

List Price: $\$ 4.95$

Send orders to:

International Reading Association

Box 695

Newark, Delaware 19711 


\section{TEACHERS COLLEGE PRESS}

Just Published

Colonel Francis Parker

The Children's Crusader

Jack K. Campbell

Parker's impact on the shaping of American education becomes evident in this significant biography. His vital personal involvements in the great events of his time, together with his association with such notable contemporaries as the Adamses and John Dewey, are treated with rare insight and careful scholarship.

Cloth, $\$ 5.00$

Progressive Education:

From Arcady to Academe

Patricia Albjerg Graham

In this first comprehensive history of the Progressive Education Association, the influence of leading practitioners is traced with great care. The institutionalization of an idea is here detailed and documented, with much closer attention to internal disputes within the movement than is offered by any other published work dealing with the period.

Cloth, $\$ 5.75$

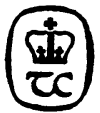

Teachers College Press

Teachers College, Columbia University

525 W. 120th St.

New York, N.Y. 10027 